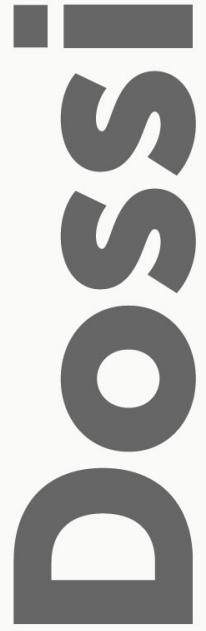

\title{
Tipologías y re-mediación de las imágenes de muerte y duelo compartidas en la memorialización online
}

\author{
Typologies and re-mediation of the images of death \\ and grief shared in online memorialization
}

\section{RESUMEN}

El presente artículo aborda el análisis de las diversas representaciones fotográficas de la muerte y el duelo y sus diversos usos publicadas en los tributos y páginas de homenaje a los difuntos en Internet por los dolientes. La investigación ahonda a su vez en el valor que obtienen estas imágenes una vez recontextualizadas en el duelo, así como también de la respuesta generada por familiares, conocidos y también a menudo usuarios desconocidos, una vez son publicadas y remediadas. Con este artículo se pretende analizar el uso de la imagen en el ámbito online como una herramienta para visibilizar la muerte en el entorno íntimo, así como el papel de la imagen digital como mediadora en la comunicación, apoyo y visibilización de las personas en duelo mediante las reacciones producidas ante la publicación de dichas imágenes, y como elemento clave en la creación de nuevos rituales de duelo en el entorno no presencial.

Palabras clave: Muerte - Imagen digital - Memoriales online - Duelo Remediación - Co-presencia

\begin{abstract}
This article analyses various photographic representations of death and grief and its uses by the bereaved when published in tribute or memorialization sites on the Internet. Research, in turn, delves into the value of these images in the context of grief, as well as the response generated by relatives, acquaintances and often also strangers, once they are published and remediated. This article intends to analyse the online use of the image as a tool to visualize death in an intimate environment, as well as the role of the digital image as a mediator of communication, support and visibility of people in grief through the reactions produced by the publication of these images, and as a key element in the creation of new grieving rituals in the online environment.
\end{abstract}

Keywords: Death - Digital image - Online memorials - Grief - Remediation - Co-presence

* Pos-doctora en el Departamento de Antropología de Columbia University y en el Morbid Anatomy Museum (New York). Doctora en Bellas Artes por la Universidad de Barcelona. Profesora de fotografía del Departamento de Artes Visuales y Diseño (Facultad de Bellas Artes, Universidad de Barcelona). Pertenece al grupo de investigación "Compartiendo el dolor y el duelo online: la imagen digital autorreferencial de la enfermedad y la muerte como elemento de desestigmatización, conexión, visibilización y copresencia" becado por Ayudas Fundación BBVA. CV: https://ub.academia.edu/MontseMorcate 
La muerte y el duelo han sido representados por el medio fotográfico desde su aparición, siendo la fotografía una herramienta que ha sabido adaptarse a las diferentes actitudes frente a la muerte desde la segunda mitad del siglo XIX hasta nuestros días (Burns, 1990; Ruby, 1999; Morcate, 2014). Es bien conocido cómo la fotografía post mortem y otras imágenes de representación del duelo tuvieron una importante aceptación y fueron un elemento imprescindible de los rituales funerarios colectivos y también de otros de carácter más íntimo. No obstante, y a pesar de su progresiva decadencia en la segunda mitad del siglo XX, la fotografía de la muerte y el duelo siguió realizándose, aunque en algunos contextos de manera más clandestina que pública. Entre los usos más habituales de este tipo de imágenes se encuentran la captación del semblante del difunto para perpetuar su recuerdo, la fotografía como herramienta documental para la difusión del deceso o la creación de una imagen conmemorativa que pueda representar y vehicular la pérdida.

Resulta interesante cómo, tras una segunda mitad de siglo XX con una creciente rechazo de estas prácticas, con la llegada del siglo XXI se produce un progresivo incremento de la representación de la muerte y el duelo a través de la imagen online, motivado por la coalición de diversos factores tales como los cambios producidos en ciertas actitudes frente a la muerte y el desarrollo de la industria funeraria, pero también en los últimos años muy especialmente por el desarrollo de la imagen digital, la expansión de Internet y el uso masivo de las redes sociales (Mitford, 2000; Massimi y Baecker, 2010; Walter, 2012).

En este sentido, en pocos años se multiplican de manera exponencial diversas plataformas online para el homenaje y el recuerdo de los difuntos (tanto desde iniciativas privadas, como sin ánimo de lucro, o iniciativas espontáneas surgidas desde las redes sociales). Con la progresiva expansión de Internet y la aparición de redes sociales, aparecen numerosos artículos académicos que plantean diversas cuestiones relacionadas con las manifestaciones de duelo y la visibilidad de la muerte en el terreno online. Y es que como apunta Amanda Lagerkvist: "En la era de los medios de comunicación, la muerte está en todas partes: en las noticias, en la ficción, y en particular en las prácticas sociales y conmemorativas en internet" (Lagerkvist, 2013, p.8). ${ }^{1}$ Así, la presencia de la muerte en Internet es considerable, lo que plantea cuestiones respecto a cómo el terreno online reúne unas condiciones específicas que facilitaría a los dolientes expresar su duelo así como la creación de nuevos rituales mediatizados (Sumiala, 2013) distintos a los ya existentes en el terreno presencial, que podrían estar cambiando ciertas actitudes frente a la muerte y el duelo en la actualidad. En buena parte de estas manifestaciones de duelo online, el uso de la imagen resulta un elemento clave, no sólo porque en muchas de estas plataformas el carácter visual es predominante sino también porque la imagen se convierte en mediadora del proceso de duelo a través de la cual generar reacciones sobre la muerte y la pérdida.

El gran número de estas plataformas y la gran cantidad de interacciones que presentan, plantea la hipótesis sobre la capacidad específica de la imagen digital como generadora de diálogo con los dolientes en el terreno online que facilite el intercambio de condolencias y apoyo al doliente de un modo mucho más versátil que en el entorno presencial. Así mismo se cuestionan por qué numerosas imágenes de representación de la muerte literal o evocada y compartida en estos memoriales suelen tener una aceptación considerablemente positiva frente al rechazo que estas mismas imágenes

1 "Death is everywhere in the media age: in news, in fiction, and not least in the budding practices of sociality and memory on the internet" (Traducción de la autora. En adelante, se mencionará como T. A.). 
tendrían en el terreno presencial o si estas fueran publicadas por los medios de comunicación, fuera de un contexto de duelo compartido.

Para intentar analizar el uso y la aceptación de las diversas tipologías de imágenes de representación de la muerte y el duelo que se comparten online, es preciso abordar los elementos clave que han permitido esta progresiva exposición de este tipo de imágenes, por lo que se propone examinar las prácticas fotográficas y la interacción que estas suscitan. Con esta finalidad, se ha empleado una metodología cualitativa, así como un análisis semiótico posterior de las variedades de imágenes seleccionadas en los diversos memoriales y tipos de páginas conmemorativas que resultan más representativas. Por otra parte, se ha acotado la investigación al análisis exclusivamente de las imágenes compartidas en páginas y memoriales públicos o abiertos. A pesar del carácter abierto de los mismos, se ha optado por no incluir las imágenes en estas páginas. Esta decisión se debe por una parte a la incapacidad en algunos casos de contactar con los propietarios de algunas de las imágenes (el hecho de compartirlas públicamente no implica el libre uso por parte de terceros), pero muy especialmente a la importancia de acceder a las imágenes en su contexto original tal y como la persona en duelo desea compartirlas (éstas se encuentran online y en abierto por lo que son accesibles para el lector que desee consultarlas).

Es innegable cómo las prácticas fotográficas recientes están alterando ciertos valores asociados a la imagen y el uso que de ellas se hace. Ciertamente, uno de los aspectos que más está transformando el modo en el que la sociedad se relaciona con las imágenes llega de la mano de la imagen digital compartida en Internet. Como apuntan diversos autores la imagen se emplea como una herramienta de conexión, comunicación y co-presencia gracias al hecho de compartir imágenes con otros usuarios (Ito, 2005; Van House, 2011). De este modo el acto fotográfico deja de tener como finalidad principal la creación de documentos para la preservación de la memoria en el entorno íntimo. Así, "Las fotos se comparten menos en el contexto familiar y privado y más en un entorno de grupo afín." (Van Dijck, 2008, p. 61). ${ }^{2}$ Se trata, por tanto, de anteponer el compartir experiencias a través de imágenes para establecer vínculos que el mero hecho de perpetuar el recuerdo. De este modo, compartir imágenes online permite la comunicación y la creación de lazos más allá de nuestro entorno presencial.

Este enfoque de la imagen y su uso compartido online permiten articular cuestiones más específicas en torno al tema principal, tales como cuáles son las diversas representaciones de la muerte y el duelo y el valor que éstas tienen para el doliente; cuáles son las características específicas de la imagen digital compartida en Internet y cómo estas imágenes se mediatizan para generar nuevos rituales de duelo. Así, la creación de memoriales, perfiles y páginas de homenaje online facilita, mediante la participación e interacción de usuarios, una suerte de comunidades imaginarias (Anderson, 2006) en el que las personas en duelo encuentran un entorno cómodo en el que recibir y aportar consuelo, por parte de allegados y de anónimos en situaciones similares, entre iguales.

La imagen digital compartida, deja de ser únicamente portadora de memoria, sino que también es empleada para ofrecer la visibilidad que muchas personas en duelo necesitan, y de manera fundamental, se utiliza como mediadora de experiencias de duelo con otros usuarios, facilitando el intercambio y la comunicación, así como también es utilizada en la creación de

2 "Photos are shared less in the context of family and home and more in peer-group environment" (T.A.). 
nuevos rituales de duelo. Por tanto, aquí la imagen es claramente remediada (Bolter y Grusin, 2000), entendiendo el término como el proceso de re-contextualización de imágenes familiares en el terreno online, siendo aquí el compartir y exponer las imágenes en el ámbito específico del duelo, lo que les proporcionan nuevos valores y significados.

Para comprender este valor de remediación de la imagen, es fundamental identificar a la gran mayoría de imágenes de representación de la muerte y el duelo compartidas en este contexto como imágenes auto-referenciales para el doliente. Esto a su vez implica, que dichas imágenes pertenecen a la representación de su intimidad y que por tanto suelen formar a su vez parte de su álbum o archivo familiar. El archivo familiar es desmenuzado, recontextualizado y reinterpretado en muchas de las páginas y galerías memoriales, en las que se conjura un nuevo álbum familiar dedicado al difunto y enfocado en la pérdida y el duelo. Entre los numerosos archivos personales y familiares compartidos, se acostumbran a entremezclar otros tipos de imágenes con un contenido más simbólico, como flores o cielos, junto a otras imágenes manipuladas digitalmente y a menudo reapropiadas de la red, tales como estampas digitales con algún elemento también cargado de simbolismo junto al texto en el que a menudo se expresan sentimientos o condolencias.

La finalidad de compartir estas imágenes de carácter privado, no sólo con los allegados, sino muy a menudo con otros usuarios anónimos que tienen acceso a las páginas conmemorativas - los obituarios online obedece al deseo de visibilización, como lo evidencia el gran número de páginas y perfiles abiertos. Se trata de una visibilización con un claro carácter dual: por un lado, visibilidad del ser querido en un intento de rendir homenaje al difunto y perpetuar su recuerdo y al mismo tiempo, visibilidad del doliente, que pasa a ser reconocido como tal, a través de la creación del homenaje, su gestión y la expresión escrita mediante sus comentarios.

En este sentido, y desde el origen de la fotografía, las imágenes de muerte y duelo han ocupado un espacio de gran importancia en la representación familiar, en las que tanto fallecido como doliente se manifiestan y expresan a través de las imágenes. En investigaciones previas realizadas por la autora acerca de las diversas representaciones fotográficas de la muerte y el duelo (Morcate, 2012 y 2014; Morcate y Pardo, 2016) se establecen diversos tipos de imágenes utilizadas, que funcionan también para su análisis en el terreno online y que se presentan a continuación.

\section{Tipologías y valores de las imágenes de duelo y muerte compartidas}

Ante la abundante variedad de tipologías de imágenes de duelo y muerte existentes se proponen dos categorías principales claramente diferenciadas: por un lado, se encuentran las denominadas "imágenes con el muerto presente" y, por otro, "imágenes con el muerto ausente". Estos dos bloques no sólo distinguen las imágenes en las que la literalidad de la muerte es representada en la fotografía respecto a otras en las que el difunto no es visible pero sí es evocado, sino también, aquéllas en las que el doliente es representado, así como de los diferentes valores que adquieren tales representaciones en el entramado del proceso de duelo.

En el primer grupo encontraríamos otros subgrupos de imágenes, como son los retratos post mortem, los retratos de duelo y otros retratos de ámbito funerario en los que también se representaría al difunto, generalmente rodeado de familiares o mostrando las exequias o el funeral. Por el contrario, en el segundo grupo se aglutinarían, entre otros, diversos tipos de representación como los retratos de luto y otro tipo de imágenes conmemorativas, a menudo de carácter 
simbólico, teniendo éstas últimas una gran variedad de tipologías que englobarían también otras prácticas fotográficas en la que se incluirían objetos conmemorativos, foto-esculturas, collages, entre otros.

La riqueza en la representación fotográfica de la muerte y el duelo que alcanzó su apogeo en la segunda mitad del siglo XIX y que progresivamente cayó en desuso en la segunda mitad del siglo XX, retoma así un nuevo auge con la llegada de la imagen digital y la posibilidad de ser compartidas en Internet. Así se retoman algunas de las tipologías decimonónicas y se reinventan otras, gracias a las posibilidades y facilidad que ofrece la imagen digital y su manipulación mediante software.

En gran parte de obituarios, páginas y perfiles memoriales o conmemorativos, el uso de la imagen está implícito y suele tener un papel fundamental. No obstante, también existen ejemplos en los que la fotografía tiene un papel menor y/o pertenecen a una primera generación de conmemorativos online todavía activos, que poseen características más estáticas de navegación. Por lo general, éstas suelen tener la estructura y contenido de obituario, en el que el texto se ilustra con una única imagen, por lo general del retrato del difunto en vida, y que tiene una función identificativa o de documento. Suelen tener, por tanto, una estructura sencilla y limitada, en la que no se produce interacción con otros dolientes y/o usuarios.

Sin embargo, en la mayoría de opciones conmemorativas online actuales, la imagen tiene una presencia predominante. Una de las plataformas online en las que mejor puede observarse la importancia que se confiere a la imagen, así como sus diversas tipologías es Much Loved. Creada en el año 2000, esta organización británica sin ánimo de lucro alberga más de 180.000 páginas conmemorativas y continúa siendo una referencia para miles de personas en duelo que optan por esta plataforma para rendir homenaje a sus difuntos. De entre todos los creados hasta la fecha, más de 11.000 son públicos, por lo que puede obtenerse un análisis representativo del papel de la imagen en su contenido. ${ }^{3}$

El tipo más común de fotografía utilizada en los tributos es la familiar, imágenes relacionadas con el difunto en vida, en el que éste suele ser protagonista y que vuelven a ser publicadas con motivo de su deceso. El número de imágenes publicadas es muy variable, yendo desde el uso de una sola imagen, tal y como se apuntó anteriormente, al uso generalizado de la galería de imágenes que suele oscilar entre una decena de imágenes, pero que en ocasiones puede llegar a contar con centenares de ellas.

Uno de los aspectos más interesantes del uso de la fotografía familiar en estos tributos reside en que constituye una recontextualización de la fotografía familiar dentro del entramado del duelo. En este sentido, la capacidad narrativa de las imágenes familiares toma una trascendencia mayor, convirtiendo las imágenes compartidas de los ritos de paso, tales como el nacimiento, los cumpleaños o la boda, así como otras instantáneas pertenecientes a fiestas, momentos cotidianos o vacaciones, en una proyección de la pérdida e indisociables de la muerte acontecida. Una proyección siempre presente en la revisión del archivo familiar tras la muerte de uno de sus miembros (Barthes, 2007), que aquí se hace especialmente tangible por tratarse de un entorno específico de duelo.

3 Se toma como caso de estudio esta plataforma debido no sólo a su elevado número de ejemplos sino también por el carácter abierto de miles de los tributos alojados. Disponible en: <http://www. muchloved.com/gateway/muchlovedcharitable-trust.htm>. Acceso en: 14 de diciembre de 2016. 
Por otra parte, la creación de las galerías, induce al doliente a una revisitación del archivo familiar, su narratividad y su significado (Hirsch, 2002; Langford, 2013), en el que éste, y condicionado por el duelo, re-edita su archivo, mediante una selección de imágenes, con la voluntad de crear un archivo fotográfico en el que el difunto es el principal protagonista (a diferencia de lo que ocurre en el álbum fotográfico tradicional en el que el protagonismo se reparte entre los miembros del núcleo familiar). De este modo, denominamos "archivo de duelo online" al conjunto de imágenes seleccionadas por la persona en duelo que surgen como resultado de la necesidad de visionar y reeditar el archivo familiar, y que tiene como finalidad el enfrentarse a la pérdida y rendir homenaje al ser querido al compartirlo en la red. ${ }^{4}$ Un proceso que hace cuestionar al doliente no sólo la relación con la persona fallecida sino también la imagen que se desea proyectar del ser querido a través de las fotografías escogidas.

En este sentido, la edad del difunto o el tipo de muerte, entre otros factores, no sólo condicionará el tipo de duelo (Worden, 2010; Doka, 1989; Kübler-Ross y Kessler, 2010) sino que también determinará en cierta medida el tipo de tributo $y$, consecuentemente el tipo de galería creada. Así, pueden encontrarse ejemplos muy diversos como el memorial de C.J.5 (1935-2016) con sólo dos retratos del difunto a modo de díptico y que destacan por representarlo de joven y de adulto con el mismo semblante sonriente, lo que transmite de una manera sencilla la voluntad de representarlo como a una persona alegre a lo largo de su vida; a otras como el memorial de S. $B^{6}$. (1993 - 2013), en el que más de 60 instantáneas en las que aparece la difunta de adulta rodeada de familiares y amigos, con la voluntad de transmitir sin orden cronológico el gran número de personas que estaban vinculadas a ella.

A modo de ejemplo, las galerías de imágenes incluidas en los tributos de los jóvenes acostumbran a tener numerosas imágenes que suelen representar al difunto no sólo rodeado de familiares sino también de los amigos de juventud, mostrándolos a través de las imágenes como personas llenas de vida y queridas por su entorno, frecuentemente con numerosas imágenes pertenecientes a la última etapa de la vida. Por el contrario, en el caso de personas fallecidas con edad avanzada, es frecuente realizar una síntesis del clásico álbum familiar, mostrando los ritos de paso, con la voluntad de proyectar la visión de una vida plena rodeada de los suyos.

Otros tipos de imágenes que representan el duelo y la muerte de forma literal pueden encontrarse cada vez con mayor frecuencia en los memoriales online. Entre ellos se encuentran los retratos post mortem, que gradualmente han encontrado una mayor aceptación gracias al contexto en el que suelen hacerse públicos, tales como páginas conmemorativas o tributos online. Aunque los retratos de los familiares difuntos nunca han dejado de realizarse, pasando de una aceptación generalizada a una práctica cercana a la clandestinidad, en la actualidad la mayoría de retratos post mortem que se comparten en estas plataformas pertenecen a recién nacidos. Si bien diversos autores afirman que la práctica de la fotografía post mortem así como del uso de la fotografía para documentar objetos y detalles del difunto es cada vez más defendida por los profesionales y adoptada por los dolientes (Sherr, 1992; Morcate, 2012; Pardo y Morcate, 2016), no por ello no deja de crear controversias y debates públicos cuando dan el salto fuera de

\footnotetext{
4 Puede aplicarse el mismo término a los archivos generados por una o un conjunto de personas en duelo y fuera del núcleo familiar.

5 Disponible en: <http://colin.jones.2016.muchloved.com/>. Acceso en: 8/05/2017.

6 Disponible en: <http://shelby.boarer.muchloved.com/>. Acceso en: 7/05/2017.
} 
los entornos específicos de duelo.' En Much Loved pueden encontrarse numerosos ejemplos de tributos a recién nacidos fallecidos (o fallecidos poco después de nacer) en los que el uso de la fotografía post mortem está presente en sus diversas variaciones.

Aunque es cierto que en algunos tributos dedicados a bebés o niños se opta por utilizar sólo una imagen simbólica, como la imagen por defecto de un oso de peluche, pueden encontrarse sin embargo numerosas galerías con abundantes fotografías. Algunas de ellas, muestran una variedad sorprendente de usos fotográficos y una clara voluntad de narratividad. En la galería de M.B. ${ }^{8}$ los progenitores comparten todas aquellas imágenes tomadas desde el inicio de la gestación. Así, puede verse una ecografía a las veinte semanas de embarazo, que sin duda pone en valor los meses de gestación como tiempo de existencia del hijo deseado. Le siguen diversos retratos en color del bebé fallecido al nacer prematuramente, algunos primeros planos y otros en brazos de su madre, su padre y su abuela. En este caso, todas las fotografías presentan una estética amateur y realizada probablemente entre los familiares, a diferencia de otros casos en los que se requiere del servicio de un fotógrafo profesional (Morcate, 2012 y 2014).

A estos retratos de familia, le siguen otras imágenes de carácter funerario en las que destacan la fotografía en primer plano de un ataúd rosa cerrado, con el título "pink coffin" y otras dos imágenes del ataúd abierto con el bebé en él en el que se observa al difunto acomodado en dos primeros planos. La serie de imágenes finaliza con la fotografía de la placa del ataúd con el nombre del ser querido inscrito. Una galería que resume de manera gráfica la brevedad de la existencia del ser querido y que reúne los rituales del nacimiento y la despedida. Otro tipo de galería similar, aunque incluso más rica en cuanto a los diversos usos de la imagen puede encontrarse en la de J.D. en la que se repite el ritual fotográfico en el que los familiares se retratan junto al bebé transformando la sesión fotográfica en un ritual previo a la despedida definitiva. En esta galería, sin embargo, le acompañan otras imágenes más elaboradas, con una estética más profesional en la que diversos retratos en un blanco y negro cuidado del rostro del bebé se complementan con un primer plano de la mano de la madre sosteniendo la diminuta mano del recién nacido titulada "Ahora los ángeles te toman de la mano"9 y diversas imágenes en color del bebé aún con vida junto a una imagen del equipo médico en el que se indica su temperatura y su tamaño, entre otros datos. Manifestación clara de la voluntad de registrar los instantes de vida del ser querido. Otras imágenes de tipo más simbólico complementan la galería, como una composición en el que una fotografía de detalle de los pies desplegados en forma de " $\mathrm{V}$ " sirve para componer la palabra "Love" gracias a la superposición de las letras impresas. La galería no se limita a documentar la experiencia vivida en el hospital sino que está compuesta de otras imágenes a modo de documento, como son la impresión en tinta de las huellas de los diminutos pies a modo de certificado, la inclusión del obituario y la imagen final de la lápida del bebé. Se hace evidente el deseo explícito de cerrar, mediante la narración visual, el ciclo vital de una vida, desde el nacimiento hasta la muerte prematura.

También pueden encontrarse diversas galerías conmemorativas en casos de abortos

\footnotetext{
7 Se analiza uno de estos casos como contrapunto a la aceptación de estas imágenes en contextos de duelo en la parte final del artículo.

8 Disponible en: <http://madeleine.brown.muchloved.com/>. Acceso en: 4/05/2017.

9 Angels hold your hand now" (T.A.)
} 
espontáneos muy precoces, como la dedicada a las gemelas M. y E. ${ }^{10}$ en las que se repite la voluntad de la madre por posar junto a sus hijas perdidas. Diversas fotografías de las gemelas en primer plano muestran unos fetos de apenas unos centímetros. Imágenes en las que el contraste creado por la falta de desarrollo de ambas y el posado claramente maternal de la madre que las acoge con delicadeza en su pecho, producen un fuerte contraste. A éstas, se suma el retrato de la madre besando a sus hijas, otras de detalles de pies y manos y un nuevo retrato junto a la madre titulado "Las chicas entre mis brazos por última vez". ${ }^{11}$ Como en otros casos de pérdidas muy tempranas, la galería no se crea exclusivamente para centrarse en los momentos más duros, sino para celebrar todo el proceso compartido, desde la imagen tomada al test de embarazo dando "positivo", las ecografías o una fotografía más elaborada en la que la madre posa embarazada junto a un texto con los nombres de las niñas. Quizás la imagen más sorprendente sea la tarjeta anunciando el nacimiento de las gemelas, en las que el diseño de texto con la información se complementa con varias fotografías de los fetos a modo de mosaico, presumiblemente compartidas entre familiares y amigos

Son en casos como éste, pérdidas muy tempranas por aborto espontáneo o muerte perinatal, en los que la imagen adquiere un valor de amplificador de la vida, ya que la incorporación de ciertas imágenes tales como las ecografías o la barriga de la madre en crecimiento, sirven como "pruebas visuales" que visibilizan y extienden el periodo temporal en el que el ser querido ha estado presente y ha tenido una existencia real, al menos para los progenitores.

En casos como estos, en los que se comparten imágenes post mortem de bebés y fetos (aunque reconocidos por sus seres queridos como hijos perdidos y deseados) resulta interesante observar los comentarios que generan dichas imágenes, evidenciando la aceptación por parte de quien visita la galería de las mismas sin importar su crudeza. Así, es frecuente encontrar comentarios de apoyo por parte de desconocidos ante la publicación de fotografías post mortem, aunque éstas sean imágenes directas y poco cuidadas, tales como el caso de C.B. que envía su pésame a la madre de L.A. ${ }^{12}$ quien comparte su galería con las fotos de su bebé muerto:

Siento mucho leer sobre la trágica pérdida de tu hermoso y querido bebé L., y quisiera ofrecerte mi más sentido pésame para ti y tu familia. Por favor, acepta mis condolencias sin que te molestes porque no te conozco; pero realmente espero que encuentres bienestar y esperanza en estos versos. ${ }^{13}$

La creación de galerías en este tipo de pérdida muestra claramente el papel de la imagen como mediadora del duelo y como herramienta para vehicular la necesidad de hacer real no sólo la existencia de los seres queridos sino la propia pérdida, a menudo no reconocida por el entorno.

A modo de ejemplo de este tipo de pérdidas, se toma un tributo un tanto singular por su enfoque colectivo, dirigido al homenaje colectivo de niños y bebés fallecidos, bajo el nombre

10 Acceso en http://maeve.eleanor.muchloved.com/>. Acceso en: 4/052017.

11 "Last time holding the girls". (T.A.).

12 Disponible en: <http://luke.ayres.muchloved.com/>. Acceso en: 8/052017.

13 "I'm very sorry to read of the tragic loss of your precious, beloved baby son L., and I want to offer my heartfelt sympathy to you and your family. Please accept my condolences without taking offence, because I don't know you; but I really hope that you will find comfort and hope in these verses". (T.A.) 
"Recordando a todos nuestros angelitos..." ${ }^{14}$ En esta galería colectiva y plural, se reúnen algunos de los ejemplos ya comentados en los que se resumen la mayoría de tipologías de fotografía post mortem y de duelo, retomando en muchos de los casos su uso primigenio (captar el semblante del difunto), en los casos en los que el bebé hubiera nacido muerto o fallecido al poco tiempo de nacer. Sin embargo, también aquí se pueden encontrar imágenes de duelo, en la que la madre posa con su hijo, creando mediante el acto fotográfico un ritual de despedida. De nuevo se encuentran diversas imágenes pertenecientes a fetos, cuyas imágenes son tomadas y compartidas con la finalidad de hacer real su existencia como hijos deseados, así como otro tipo de imágenes como las ecografías, en las que se pretende manifestar de un modo mucho más velado y sutil la vida perdida del ser querido en la imagen. El hecho de compartir estas imágenes en una galería colectiva acentúa la voluntad de los dolientes por hacerse visibles y formar parte del colectivo.

En tributos como este, los comentarios suelen ser numerosos, en los que a menudo, la imagen publicada es el motor que genera condolencias y/o promueve el compartir experiencias similares de duelo por parte de personas anónimas. Es precisamente en este contexto donde puede observarse cómo incluso las imágenes más literales de muerte y duelo encuentran una audiencia que comprende la necesidad de compartirlas y que se centra más en lo que simbolizan dichas imágenes que en su estricta representación. A raíz de las fotografías post mortem de esta galería, S.R. escribe:

Cuando veo todas estas fotos me pongo triste porque no tuve la suerte ni siquiera de tener una foto o vestir a mi bebé. En el hospital envolvieron a mi querido bebé muerto- de piel y cabello claro - en una sábana de hospital y me lo trajeron para que lo cogiera 30 segundos. Ni siquiera esperaron a que llegara mi marido. ¡Fui la única en ver al bebé y el único comentario fue que era un feto blanco! ${ }^{15}$

Uno de los muchos ejemplos en los que usuarios anónimos ven reflejados su propio proceso de duelo a través de imágenes de terceros, visibilizando su propio dolor, lo que promueve el reconocimiento entre iguales y la voluntad por mostrar apoyo.

Por otra parte, las imágenes que muestran el funeral o elementos funerarios, además de otras fotografías tomadas posteriormente a la muerte del ser querido, fruto de algún ritual privado o público como homenaje póstumo o una pieza conmemorativa a partir de imágenes son cada vez más frecuentes. Pueden encontrase ejemplos de memoriales en los que tan sólo aparece una imagen simbólica del ritual, tal como una imagen de un ramo de flores, hasta galerías en las que se comparte el reportaje fotográfico del funeral, incluyendo la vista del ataúd abierto, la ceremonia y los asistentes, como sucede en el memorial a R. K. ${ }^{16}$ (1953-2009).

\footnotetext{
14 "Remembering all our little angels". (T.A.).

15 "When I see all these photos it makes me so sad because I didn't have the luck to even have a photo or my baby dressed. The hospital wrapped my lovely stillborn son -with light hair and fair skin- in a hospital sheet and brought him for me to hold for 30 seconds. They did not even wait for my husband to arrive. I was the only one to see the baby and their only comment was that he was a white foetus!" (T.A.). Disponible en: <http://all.our.little.angels. muchloved.com/>. Acceso en: 8/05/2017.

16 Disponible en: <http://rebecca.kiyingi.muchloved.com/>. Acceso en 6/05/2017.
} 
La exponencial expansión de los teléfonos móviles con cámara y la facilidad de compartir imágenes a través de las redes, ha hecho que la difusión e intercambio de imágenes cotidianas se haya convertido en una práctica común. Esta tendencia también ha alcanzado a las imágenes de representación de la muerte y el duelo. A este respecto, se han realizado diversos estudios, algunos de los cuales se centran en el incremento de imágenes tomadas con motivo de un funeral, especialmente de selfies, creando numerosos debates y controversias sobre la legitimidad de realizar y compartir estas imágenes y de lo apropiado de las mismas (Gibbs, Nansen et al., 2014; Gibbs, Meese, Arnold, et al., 2014). Cabe apuntar, sin embargo, que las imágenes compartidas en los tributos analizados han mostrado una vinculación afectiva con el difunto y todas ellas tienen exclusivamente la finalidad de rendir homenaje al ser querido, por lo que ningún comentario detectado cuestiona en modo alguno la presencia de éstas en las galerías. ${ }^{17}$

A modo de ejemplo, se encuentra el memorial de A. C. H. ${ }^{18}$ (1988 - 2007) con una galería de más de cien imágenes, y en las que además del conjunto habitual de fotografías familiares, se pueden encontrar imágenes de la tumba rodeada de flores con motivo del aniversario del difunto, entre otras similares. Es en memoriales como éste, dedicados a los más jóvenes, en los que la interactividad con otros usuarios es mayor. Además de familiares, amigos y conocidos, son abundantes los comentarios por usuarios anónimos que desean compartir sus experiencias y ofrecer consuelo al tiempo que hacen visible su pérdida. Como F. M. que comenta: "Qué joven más guapo y el hijo más amado. Tuve un hijo de su edad que murió en Afganistán. Te envío amor y esperanza porque quiero creer que estaremos todos juntos algún día"19

Si bien en este tipo de tributos existen numerosos comentarios que hacen referencia a las imágenes, haciendo visible la interacción por parte de los usuarios gracias a éstas, la estructura física del mismo, separando las imágenes de los comentarios, hace menos tangible que en otro tipo de opciones tales como las páginas o perfiles conmemorativos en redes sociales esta interacción de imagen y texto.

El número de páginas y perfiles conmemorativos incrementa año tras año y tanto su utilidad como herramienta de superación de la pérdida como la gestión del legado digital han sido motivo de numerosos artículos (Sumiala, Hakola, 2013; Brubaker, Hayes y Dourish, 2013). Sin embargo, el papel específico que posee la imagen como mediadora en la expresión del duelo con otros usuarios es un territorio menos explorado.

\section{Mediación y remediación de la imagen de duelo compartida online}

Para ilustrar la capacidad de mediación y remediación de la imagen en estos contextos, se ha optado por tomar un ejemplo especialmente interesante en el que pueden observarse claramente el funcionamiento de comunidad y el papel que en ésta tiene la imagen. "En memoria

17 No se incluye aquí el estudio de imágenes etiquetadas como sí lo hacen los autores mencionados en el que tales imágenes pueden publicarse fuera del ámbito de duelo y/o tomarse por otros motivos más ambiguos o controvertidos.

18 Disponible en: <http://hunty.muchloved.com/>. Acceso en: 8/05/2017.

19 "what a handsome young man and nothing more precious than a loving son. i had a son your age who died in afghanistan. i send all of you love and hope because i like to believe we will all be together one day" (T.A.). Disponible en: <http://hunty.muchloved.com/>. Acceso en: 8/05/2017. 


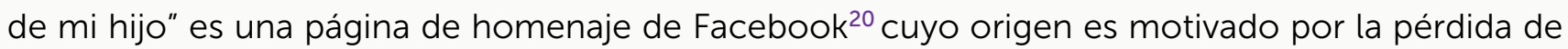
un hijo pero que rápidamente se transforma en depositaria de los duelos de otras madres por sus hijos, tal y como demuestra la propia descripción de la página y legitimado por los numerosos seguidores. ${ }^{21}$ Lo que resulta especialmente interesante de este caso es cómo la imagen como mediadora del duelo se manifiesta de una manera muy literal, tanto por parte de la creadora como por parte de sus seguidoras, a través de la creación de diversos rituales sencillos en los que la imagen es el elemento clave.

Uno de los que más se repiten es el que los propios usuarios denominan collage, composiciones a partir de las fotografías que envían otras madres de sus hijos fallecidos. Estos collages o fotocomposiciones digitales muestran, en varias formas y formatos, una matriz de retratos, la mayoría primeros planos o fotografías reencuadradas en el rostro, en las que se suceden los hijos perdidos de las madres que envían las imágenes, algunos de los cuales incluyen el nombre de cada uno de ellos.

En estos collages, se observa claramente el valor mediador y remediador de la imagen. En un primer lugar, la imagen se comparte en un nuevo contexto para hacer visible la pérdida sufrida por cada madre, adquiriendo un nuevo valor que pasa de ser una imagen familiar a una imagen de duelo. Además, la imagen es posteriormente transformada, convirtiéndose en un nuevo objeto de duelo colectivo empleado para cohesionar a la comunidad, que se hará especialmente visible mediante estos rituales fotográficos. A modo de ritual y con cierta periodicidad, se publican estas composiciones, produciendo un elevado número de comentarios. "Muchas gracias salió mi bebé mi campeón mi D. F. gracias dios lo bendiga saludos"22, "Si Madrecitas nos une el mismo dolor de no tener a nuestros hijitos muy linda la foto me reconforta el alma gracias besos". ${ }^{23}$

Los comentarios se producen con la misma intensidad cuando las fotografías no han sido seleccionadas, lo que confirma la importancia para los usuarios de sentirse representados mediantes estos sencillos rituales: "No salió mi hijo amiguita". ${ }^{24} \mathrm{~A}$ lo que se responde: "no te preocupes en el de mañana."

Este ritual fotográfico mediatizado ejemplifica claramente el papel de la imagen digital en este contexto, que no obedece únicamente a la voluntad de perpetuar el recuerdo sino muy especialmente a la voluntad por parte de los dolientes a conectarse, reconocerse y hacerse visibles, como lo demuestra el incontable número de comentarios de este tipo que se generan como respuesta a la publicación de las piezas colectivas: "Todas estamos en este dolor y aquí es una forma de poder expresar a través de tus palabras lo que en realidad sentimos aún más cuando necesitamos apoyo, y tal vez una ilusión de volvernos con ellos." o "GRACIAS a ti querida amiga por tus publicaciones y por la manera en que haces más llevadero los momentos difíciles de cada una de las que tenemos un hijo en el cielo". ${ }^{25}$

La publicación de imágenes del hijo de la creadora de la página se comporta como reactivo

\footnotetext{
20 Se toma este ejemplo por ser especialmente ilustrativo del objeto de estudio y por tener acceso abierto como el caso anterior. Disponible en: <https://www.facebook.com/alvaro2304/>. Acceso en: 8/052017.

${ }^{21}$ La página tiene 15.362 "me gusta".

22 Disponible en: <https://www.facebook.com/alvaro2304/>. Comentario de A.R. G. V. y publicado el 18 de abril de 2016.

23 Idem. Comentario de M. S. y publicado el 18 de abril de 2016.

${ }^{24}$ Idem. Comentario de P. M. y publicado el 18 de abril de 2016.

25 Idem. Comentario de E.Z. y M. Y. y publicado el 13 de mayo de 2016.
} 
de otros intercambios de imágenes de los hijos de otras madres que se comparten de manera constante, generando a su vez nuevas expresiones de duelo, lo que permite la creación de lazos y el fortalecimiento del grupo. A estas imágenes extraídas del archivo familiar, se añaden la creación de imágenes conmemorativas, gracias al uso de programas de edición fotográfica, que recuerdan a una actualización de piezas conmemorativas fotográficas decimonónicas (Batchen, 2004), en las que se combina la imagen del fallecido con texto y otras imágenes evocadoras, como nubes, palomas, entre otros, transformando el valor primigenio de la imagen familiar en manifestaciones visuales específicas de duelo. De nuevo, la autora de la página se ofrece para crear estas sencillas piezas de acabado amateur a las otras usuarias. Un ejemplo de ello, es una pieza publicada en la que se muestra el retrato del hijo enmarcado junto a un colibrí, una flor y la palabra love. Diversas usuarias reaccionan: "Hermoso amiga me haces uno parecido o igual de mi ángel por favor gracias". 26

Este tipo de interacción se reitera por parte de numerosos usuarios, que desean repetir el homenaje y el recuerdo al ser querido mediante sencillas piezas conmemorativas. A través de la repetida interacción mediantes estos rituales mediatizados, los dolientes se sienten visibles y cómodos compartiendo el dolor, a la vez que mantienen viva la memoria del fallecido, fortaleciendo el vínculo con los miembros de la comunidad de duelo online.

Como contrapunto final a esta aceptación generalizada de las imágenes en los contextos específicos de duelo, cabe señalar cómo la presencia de ciertas imágenes de representación de muerte y duelo en otros contextos pueden crear ciertas controversias o incluso ser censuradas por considerarse demasiado explícitas e inapropiadas.

Uno de los casos recientes de mayor repercusión es el de la estadounidense Rosalyn Racca, quien decidió compartir unas imágenes junto a su bebé prematuro muerto como homenaje tras un año de la pérdida en su perfil de Facebook.27 Son imágenes de diversa índole que repiten algunas de las tipologías mencionadas. Una de ellas, muestra a la madre en la cama del hospital posando junto a su bebé prematuro difunto sobre su falda, mostrando la crudeza de la pérdida. Otras, se centran exclusivamente en su hijo, que es fotografiado con delicadeza rodeado de un tejido de punto azul y tela blanca, mostrando claramente unos rasgos formados que contrastan con la evidencia de una falta de desarrollo del feto y su color rojizo. También comparte otras imágenes de carácter más simbólico como el detalle de los pies junto a un crucifijo. La causa de que este caso se haya convertido en uno de los más mediáticos se debe a que Rosalyn Racca, recibe, tras publicar estas imágenes, un aviso de Facebook en el que se le comunica que su cuenta puede ser cerrada si no se retiran las imágenes alegando que son "gráficamente violentas". Indignada, y lejos de eliminarlas de su perfil, decide continuar publicándolas y animando a otros usuarios a compartidas. Los post públicos de Racca, se van llenando progresivamente de comentarios de apoyo por parte de familiares y de otras madres con similares experiencias. Durante un periodo especialmente activo,28 la madre reivindica la pertinencia de mostrar públicamente las imágenes de su hijo y postea la repercusión mediática del caso como un éxito: "Fue un milagro. Y no lo esconderé. 9 pulgadas y 9 onzas de perfección". "Una respuesta negativa entre más de 100 (varias me las enviaron directamente a mí).

26 Idem. Comentario de L.R.B. y publicado el 6 de abril de 2016.

27 Entre los numerosos artículos publicados en diversos medios véase éste en: <http://www.telecinco.es/informativos/ sociedad/Rosalyn-Paul_Racca-bebe_recien_nacido-censura_Facebook_0_2063775551.html>. 8/05/2017.

28 A lo largo de octubre de 2015 y los meses posteriores son los más activos y activistas del perfil. Disponible en: https:// www.facebook.com/rosalyn.guidry.3>. Acceso en: 8/05/2017. 
No está mal. Vamos a hacer que la historia de Tate tenga alcance nacional". ${ }^{29}$

A su vez, Racca va compartiendo otras iniciativas sobre la concienciación de la pérdida perinatal, y a los comentarios de apoyo generales recibidos se van sumando otras madres que deciden compartir sus propias imágenes, transformando el contenido del perfil personal en otro de mayor trascendencia y de carácter colectivo, erigiéndose como ejemplo para otras madres: "Conozco tu dolor. Pasé por esto en 2011. Mi hijo Lane nació muerto a las 30 semanas. NUNCA lo superas pero se sobrelleva. Estoy aquí por si quieres hablar. Feliz cumpleaños en el cielo Tate". ${ }^{30}$

Este ejemplo reciente pone de manifiesto de un modo muy directo la necesidad que tienen los dolientes por dar visibilidad a sus pérdidas y la importancia del apoyo colectivo en normalizar su difusión. Al mismo tiempo se evidencia cómo urge una mayor concienciación y una exhaustiva revisión en las normas de publicación en las redes sociales sobre los contextos específicos de las imágenes y las controversias que puede crear una tipificación generalista ${ }^{31}$ y errónea de las imágenes compartidas, no únicamente en este ámbito pero sí muy especialmente en los contextos de duelo.

\section{Conclusiones}

La representación de la muerte y el duelo parece haber encontrado una renovada y considerable presencia en el entorno online gracias a las nuevas prácticas asociadas a la imagen digital, su publicación e intercambio en internet. El entorno específico de duelo favorece la aceptación de imágenes más literales y descriptivas de la muerte, en el caso de las fotografías post mortem, o de momentos de recogimiento e intimidad como pueden ser las imágenes tomadas en los funerales porque son imágenes auto-referenciales utilizadas para representar el proceso de duelo de quien las comparte.

Las imágenes pertenecientes al archivo familiar se remedian en nuevos contextos de duelo donde adquieren nuevos valores en el duelo y sirven como herramienta de visibilización, no únicamente del fallecido sino del propio doliente. Estos archivos de duelo online, suponen una manera de enfrentarse a la pérdida a través de las imágenes, mediante las cuales se reflexiona sobre la relación con el ser querido y se decide la imagen que se desea proyectar del mismo.

El hacer públicas estas imágenes de muerte y duelo facilita la conexión y co-presencia del doliente no únicamente con familiares y allegados del difunto, sino con usuarios anónimos con quien se establecen vínculos entre iguales y/o comunidades, con los que los usuarios pueden normalizar y compartir sus procesos de duelo.

${ }^{29}$ Idem. Comentarios publicados el 2 de octubre de 2015. "He was a miracle. And I won't hide him. 9 inches and 9 ounces of perfection", "One negative response out of over 100 (several were sent straight to me). That's not bad. Let's bring Tate's story nationwide". (T.A.)

30 "I know your pain. I went through this in 2011. My son Lane was stillborn at 30wks. You NEVER get over it but you do get through it. I'm here if you ever want to talk. Happy Birthday in Heaven Tate!". (T.A.). Idem. Comentario de J.D.R. el 7 de septiembre de 2015 .

${ }^{31}$ El 21 de octubre de 2016, Facebook publica en el blog la voluntad por no ser tan restrictivos con ciertas imágenes de violencia y desnudez, aunque no especifica cuál va a ser el protocolo ni hace referencia alguna sobre las imágenes de duelo y muerte auto referenciales. Disponible en: <https://newsroom.fb.com/news/2016/10/input-from-communityand-partners-on-our-community-standards/>. Acceso en: 15/11/2016. 


\section{Referencias Bibliográficas}

ANDERSON, Benedict. Imagined Communities. 2ํㅡㄹ ed. New York: Verso, 2006. 240p.

BARTHES, Roland. La càmera lúcida. Mallorca: Lleonard Muntaner, 2007. 165p.

BATCHEN, Geoffrey. Forget me not: Photography and Remembrance. New York, Amsterdam: Princeton Architectural Press, Van Gogh Museum, 2004. 128p.

BOLTER, Jay David \& GRUSIN, Richard. Remediation: Understanding New Media. Cambridge: MIT Press, 2000. 312p.

BRUBAKER, Jed R.; HAYES, Gillian R. \& DOURISH, Paul. Beyond the Grave: Facebook as a Site for the Expansion of Death and Mourning. The Information Society: An International Journal. V. 29, n. 3, p. 152-163, 2013.

BURNS, Stanley. Sleeping Beauty: Memorial Photography in America. Altadena, California: Twelvetrees Press, 1990. 135p.

DOKA, Kenneth. J., Disenfranchised grief: Recognizing Hidden Sorrow. Lexington: Lexington Books, 1989. 347p.

GIBBS, Marcus; MEESE, James; ARNOLD, Michael; NANSEN, Bjorn \& CARTER, Marcus. \#Funeral and Instagram: death, social media, and platform vernacular. Information, Communication \& Society. V. 18, n. 3, p. 255-268, 2014.

GIBBS, Martin; NANSEN, Bjorn; CARTER, Marcus \& KOHN, Tamara. Selfies at funerals: Remediating Rituals of Mourning. The 15th Annual Meeting of the Association of Internet Researchers. (Daegu, Korea, 22-24 October 2014). Disponible en: <https://www.researchgate.net/publication/263567059_ Selfies_at_Funerals_Remediating_rituals_of_mourning >. Acceso en: 30/05/2016.

HIRSCH, Marianne. Family Frames: Photography, narrative and postmemory. USA: Harvard University Press, 2002. 304p.

ITO, Mizuko. Intimate Visual Co-Presence. Pervasive Image Capture and Sharing Workshop. (Ubicomp, 2005). Disponible en: <http://www. itofisher.com/mito/archives/ito.ubicomp05.pdf >. Acceso en: $15 / 12 / 2016$.

KÜBLER-ROSS, Elisabeth \& KESSLER, David. Sobre el dol i el dolor. Barcelona: Edicions 62, 2010. $256 \mathrm{p}$.

LAGERKVIST, Amanda. New Memory Cultures and Death: Existential Security in the Digital Memory Ecology. Thanatos. V. 22, n. 2, p. 8-24, 2013.

LANGFORD, Martha. Contar el álbum: una aplicación del marco oral-fotográfico. In: VICENTE, Pedro. (Ed.). Álbum de familia: [re]presentación, [re]creación e [in]materialidad de las fotografías familiares. Huesca: Diputación Provincial de Huesca, La Oficina, p 63-81, 2013.

MASSIMI, Michael \& BAECKER, Roland M. A Death in the Family: Opportunities for Designing Technologies for the Bereaved. CHI '10. Proceedings of the SIGCHI Conference on Human Factors in Computing Systems. (Atlanta, Georgia, USA, April 10-15, 2010). Proceedings of CHI 2010, p.1821- 
1830.

MITFORD, Jessica. The American way of death revisited. USA: First Vintage Books Editions, 2000. $296 p$.

MORCATE, Montse. Duelo y fotografía post-mortem: Contradicciones de una práctica vigente en el siglo XXI. Sans soleil: Estudios de la imagen. N. 4, p. 168-181, 2012. Disponible en: <http://revistasanssoleil.com/wp-content/uploads/2012/02/art-Montse-Morcate.pdf>. Acceso en: 05/04/2016.

Duelo, Muerte y Fotografía: Representaciones fotográficas de la muerte y el duelo desde los usos domésticos al proyecto de creación contemporáneo. Tesis (Doctoral en artes). Departamento de Diseño e Imagen. Facultad de Bellas Artes, Universidad de Barcelona, 2014. 462p.

y PARDO, Rebeca. Grief, illness and death in contemporary photography. In: THOMAS, Helen (Ed.). Malady and Mortality: Illness, disease and death in literary and visual culture. Cambridge: Cambridge Scholars Publishing, p. 245-254, 2016.

PARDO, Rebeca y MORCATE, Montse. Illness, death and grief: the daily experience of viewing and sharing digital images. In: CRUZ, Edgar \& LEHMUSKALLIO, Asko (Eds.). Digital Photography and Everyday Life: Empirical studies on material visual practices. Routledge, p.70-85, 2016

RUBY, Jay. Secure the shadow: Death and Photography in America. Cambridge, MA: The MIT Press, 1999. 232p.

SHERR, Lorraine. Agonía, muerte y duelo. México, D.F.: El Manual Moderno, 1992. 273p.

SUMIALA, Johanna. Media and Ritual: Death, Community and Everyday Life. London, New York: Routledge, 2013. 152p.

\& HAKOLA, Outi. (Ed) Thanatos. Media and Death: Representation and performance of dying and mourning in a mediatized age. V. 2, n. 2, 2013. 74p. Disponible en: <https://thanatosjournal. files.wordpress.com/2012/12/thanatos_deathandmedia_2220135.pdf>. Acceso en: 05/04/2016.

VAN DIJCK, José. Digital photography: communication, identity, memory. Visual Communication. V. 7, p. 57-76, 2008.

VAN HOUSE, Nancy. Feminist $\mathrm{HCl}$ meets facebook: Performativity and social networking sites. Interacting with computers. V. 23, n. 5, p. 422-429, 2011. Disponible en: <http://www.academia. edu/7507760/Feminist_HCl_meets_Facebook_Performativity_and_social_networking_sites $>$. Acceso en: 05/05/2015.

WALTER, Tony; HOURIZI, Rachid; MONCUR, Wendy \& PITSILLIDES, Stacey. Does the internet change how we die and mourn? Overview and analysis. OMEGA: Journal of Death and Dying. V. 64, n. 4, p. 272-302, 2012.

WORDEN, J. William. El tratamiento del duelo. Asesoramiento psicológico y terapia. $2^{a}$ ed. Barcelona: Ediciones Paidós, 2010. 286p. 